\title{
THE NETWORK OF ULAMA IN LAMPUNG: TRACING THE ISLAMIC DEVELOPMENT AND ITS INFLUENCE ON LOCAL TRADITION AND CULTURE
}

\author{
Zainal Abidin \\ State Islamic Institute Metro \\ Iringmulyo, Metro, Lampung, Indonesia, 34112 \\ E-mail:zainal.abidin@metrouniv.ac.id \\ Basri \\ State Islamic Institute Metro \\ Iringmulyo, Metro, Lampung, Indonesia, 34112 \\ E-mail: basrin8@gmail.com \\ Rahma Dwi Nopryana \\ State Islamic Institute Metro \\ Iringmulyo, Metro, Lampung, Indonesia, 34112 \\ E-mail:asmashafira@gmail.com
}

\begin{tabular}{c|c|c}
\hline Received: & Revised: & Approved: \\
10/11/2019 & $05 / 10 / 2020$ & $25 / 11 / 2020$ \\
\hline
\end{tabular}

DOI: https:/ / doi.org/10.32332/akademika.v25i2.1672

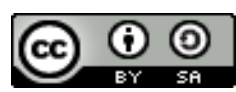

The Network of Ulama In Lampung:

Tracing the Islamic Development and Its Influence On Local Tradition And Culture Licensed Under a Creative Commons Attribution-ShareAlike 4.0 Internasional License

\begin{abstract}
This article is aimed at depicting the spread of Islam by ulama in introducing and disseminating Islam in Lampung. This article points to the three theories of the spread of Islam in Lampung. First, the theory states that Islam was originated in Banten. The second theory claims that Islam came from Pagaruyung West Sumatra through the west Lampung region. The third theory maintains that Islam was carried by Ulama from Palembang then spread from the north of Lampung. This article also confirms the contribution of Lampung ulamas. These Islamic spreaders' arrival ran accommodatingly without opposing local tradition and culture that are in line with the basic principles of Islamic teachings. The arrival of Islam enriched Piil Pesenggiri's philosophy, Pegung Pakai philosophy, and other cultural traditions. Islamic dissemination ulamas in Lampung have different
\end{abstract}


backgrounds in terms of motives of the spread and their origins. The deployment strategy is done individually as well as organized. The ulama have a network with the sultanate's political power and dealing with local rulers in Lampung. This relationship was reflected in political, economic, and familial agreements or kinship relationships through marriage between noble families from Banten and Lampung. This relationship has an impact on strengthening emotional bonds in the Islamicization process in Lampung.

Keywords: Spread of Islam, Lampung Pepadun and Saibatin,ulamas and Cultural Islamization

\section{A. Introduction}

The reality of Islam as the majority religion in Lampung is not separated from the historical perspective of the wave of Islam in Lampung. The spread of Islam in Lampung has a historical dimension which is similar to that in Java and several other regions that give birth to perspectives or theories about the entrance of Islam and its development in Indonesian archipelago. Therefore, it is interesting to conduct a research, especially the influence of Islam in changing and accommodating customs and culture, even the philosophy of Ulun Lampung (Lampung People). ${ }^{1}$

The existing research discusses three point of views. The first view claims that it was the Ulama from the Banten sultanate brought Islam to Lampung. Banten Sultanate was directly bordered by Lampung, which was separated by the Sunda Strait. The tomb of Banten ulama and some Banten sultanate's inscriptions in the Lampung region become the archaeological evidence showing a relation between Lampung and Banten sultanate. The second view states that Islam entered Lampung through the Sumatran line precisely from the sultanate of Palembang. The third view mentions that Islam was originated from the Pagaruyung Kingdom of West Sumatra ${ }^{2}$. In tracing the spread of Islam in some areas of Lampung, most historians found historical relics in the form of folklore, sacred tombs, manuscripts, several mosques, and Islamic boarding schools.

An authentic source of the entry and development of Islam was revealed by William Marsden (1754-1836), a British researcher who wrote a book on Sumatra's history on his expedition around the island of Sumatra in

1 “Sang Bumi Ruwa Jurai, Artinya Satu Bumi Dua Aliran Adat dan Budaya. Kata Sang Bumi Berasal Dari Kata 'Sanga Bumi' Artinya Se-Bumi. Sedangakan 'Ruwa Jurai' Artinya Dua Aliran (Kelompok) Budaya yang Berbeda Yaitu Aliran (Jurai/Marga), Yaitu Masyarakat Sebatin/Sai Batin (Pesisir) dan Pepadun yang Tinggal Didataran Tinggi. Ada Juga yang Menyebutnya dengan Istilah Bumi Ruwai Jurai. Dilihat Dari Silsilah Sai Batin Berasal Dari Kerajaan 'Paksi Sekala Brak', Sedangkan Kerajaan 'Abung Siwo Megow', Menjadi Cikal Bakal Masyarakat Pepadun,".

${ }^{2}$ Mufliha Wijayati, "Jejak Kesultanan Banten di Lampung Abad XVII'," Jurnal Analisis 11, no. 2 (2011): 385. 
1783. He describes Lampung in chapter sixteen of his book. Marsden urges that Islam is a religion that is majority embraced by the people of Lampung. Islam is multiplying among the people of Lampung. Almost every village already has a mosque. Nevertheless, the love of the original local superstitions is still nurtured. It encourages them to pay homage through a particular cult of their ancestors' ancient tombs with beautiful decorations and tomb protectors from weather change ${ }^{3}$. Based on Marsden's statement, it is safe to state that Lampung people have recognized the religion of Islam, and Islam has become a religion that influences predominantly applied life of Lampung people, which combines with local traditions and culture.

Almost the same as in Java, the process of Islamic entry in Java, also influenced the tradition of Javanese people who were previously religious animism and Hindu-Buddhist. The wave of Islam in Java even caused social change in various social stratums. For example, the famous Clifford Geertz research on "Javanese Religion", showed that after Islam dominated as the majority religion, it caused the emergence of variants in society namely abangan, priyayi, and santri. This group of students is a variant that emerged after Islam developed rapidly4.

The development of Islamic civilization in Lampung also colored the tradition and philosophy of life maintained in various areas in Lampung. For example, the philosophy that still lives in the middle of Lampung people is Piil Pesenggiri, which serves as a guideline of personal and public behavior in their daily lives in some villages (tiyuh, or pekon). Piil Pesenggiri is the philosophy of Lampung people since the formation and arrangement of Saibatin customs. Piil Pesenggiri comes from the Arabic word "fiil," meaning behavior, high moral, big spirit, self-recognition, rights and obligations recognition. Piil Pesenggiri is a potential area that has the meaning of a source of motivation. Therefore, everyone is dynamic in fighting for the values of a respectable life and appreciated in society. Elements of Piil Pesenggiri include Juluk Adek (Traditional Title), Nemui Nyimah (Attitude of gracious), Nengah Nyappur (Sense of Kinship), Sakai Sambayan (Mutual Cooperation) ${ }^{5}$.

This research seeks to investigate the relationship or transmission (network) of ulamas spreading Islam in Lampung through various authoritative sources originating from Lampung, Palembang and West Sumatra, as the origin of Islamic entry in Lampung, and the development of local customs and culture after the entry and development of Islam. The research question of this article is focused on two things, namely: First, how was the network of Islamic dissemination Ulama in Lampung at the beginning of its development? Second, who are the figures who play a role in the Islamization process in Lampung, and how does it affect the local

${ }^{3}$ (Marsden dkk., 2016, hlm. 445)

${ }^{4}$ Clifford Geertz and Taufik Abdullah, Agama Jawa: Abangan, Santri, Priyayi dalam Kebudayaan Jawa (Depok, Indonesia: Komunitas Bambu, 2013), 187.

${ }^{5}$ Rina Martiara, Nilai dan Norma Budaya Lampung dalam Sudut Pandang Strukturalisme (Yogyakarta: Program Pascasarjana, ISI Yogyakarta, 2012), 81. 
, Vol. 25, No. 02 Juli - Desember 2020

tradition and culture?

This research investigates the history of Islamization and its influence on the local customs and culture of Lampung people. Lexy J. Moeleong states that this type of field qualitative research cannot be released from the phenomenological paradigm and approach that is the primary setting of research. The setting of this study is used to look at various symptoms from various points of view and comprehensive analysis of existing social reality, without being shackled by the variables that often limit research ${ }^{6}$.

The approach used in this study is historical focusing on research related to the past, including the history of biographical figures, and other matters related to society that can be traced based on historical data of the past ${ }^{7}$. The historical approach is also associated with social and modern contexts, to get chronological links to the themes examined.

The main methods in this study also use observation methods (observations), documentation and interviews. Observation method is conducted by searching and observing various relics related to Islamization in Lampung, either in the form of objects or written documents. At the same time, interviews are conducted with some historians who are experts in the field of Islamic entry in Lampung. These two research methods are conducted silmultaneously in the context of field data mining and data analysis.

\section{B. The Origin of Ulun (person) Lampung}

There are several theories about the origin of the Lampung tribe. Some state that the history of Lampung tribe comes from the Sekala Brak Kingdom, of which 13 centuries were standing. The leader of the kingdom was a queen named Ratu Sekerumong or Umpu Sekekhumong. She was from the Tumi tribe, who was often believed to be the Lampung people's original ancestor. Sekala Brak kingdom was located on Mount Pesagi, while the founder of Sekala Brak kingdom is named Buay Tumi. The name Sekala Brak also has many versions. Others call it Sakala Bhra, Sekala Beghak, and Segara Brak. These names refer to the existence of the Tumi people who founded the community in the 3rd century AD, under the leadership of Buay Tumi. The religious traditions of the people at that time still adhered to ancestral traditions and Hindu influences 8 .

Sekala Brak kingdom lasted long enough, until the 16th century, came four Princes of Pagaruyung who wanted to expand the kingdom and managed to defeat the kingdom of Sekala Brak led by Queen Sekerumong (Sekekhumong) of the Tumi tribe. From then on the Tumi people were scattered, and the concept of the Hindu kingdom was replaced by an Islamic government called "Paksian". After the kingdom of Sekala Brak was divided

${ }^{6}$ (Meleong, 1989, hlm. 9-11)

7 (Moh. Nazir, 1991, hlm. 15)

8 Rina Martiara, Cangget: Identitas Kultural Lampung sebagai Bagian dari Keragaman Budaya Indonesia, 2014, 52. 
into four parts, which was ruled by four princes of Pagaruyung, namely Inder Gajah, Belunguh, Sikin and Pak Lang. ${ }^{9}$

The four Princes of Pagaruyung were then named Umpu Bejalan in Way, Umpu Belunguh, Umpu Nyerupa and Umpu Pernong. The four regions of Paksian have their own territory, people and customs and have the same seat. Under the four-packs, the civilization of the Sekala Brak kingdom then resumed and developed rapidly under the control of the four packs. Besides, it is also mentioned that the kingdom had established cooperation with kingdoms in the archipelago, India and China ${ }^{10}$.

There are several opinions on the origin of the word Lampung and its accusers as a study of Lampung's history. Some versions of opinions related to the origin of the word or term Lampung. First, according to oral tradition, according to Lampung residents, it is said that the word "Lampung" is derived from word "Anjak Lampung" (from above). The word also indicates that the ancestors of the Lampung people came from the mountainous area of Belalau plateau at the foot of Pesagi mountain located in the east of Danau Ranau or upstream of Way Semangka which boils in the Teluk SemangkaKota Agung11.

Second, the theory that states that the origin of the word "Lampung" derived from the legend of Ompung or Opung Silamponga originated from the north or precisely from North Sumatra. It is narrated in the legend that after the volcanic eruption at silamponga's ompung origin, many people dived in and many of them were victims of the eruption. As a result of the massive eruption, it eventually formed Lake Toba located in tapian nauli (Tapanuli) area in North Sumatra province. Some of those who managed to save themselves were four people named, ompung Silitonga, Ompung Silamponga, Ompung Silaitoa, and Ompung Silantanga. They searched the safe area by travelling, but the three men stopped travelling, and the toothless Silamponga continued to wander until it washed up on Krui beach, and settled there, as a farmer. One day Ompung Silamponga, went up the hill and saw the vast plains, shouting: "Lappung... Lappung", who in Batak berate language of the vast plains, finally decided to stay in the area and blend in with the indigenous people. Until now, in the Krui area, there are still many people who call Lappung or Ulun Lappung (Lampung people) ${ }^{12}$.

Third, according to Kuntara Raja Niti, it is mentioned that the Lampung people (Pubian, Abung, Coastal and others) came from Pagarruyung descended from Puteri Kayangan of Kuala Tungkal. Their relatives settled in Sekala Brak. The grandson of Umpu Serunting (Sidenting) had five sons, namely Indra Gajah (the ancestor of the Abung people),

${ }^{9}$ Ali Imron, Kuntara Raja Niti: Tra [N] Skripsi Naskah Kuno dan Analisis Sejarah (Lampung: Universitas Lampung, 1991).

${ }^{10}$ (Martiara, 2014, hlm. 53-54.)

${ }^{11}$ Sabarudin, Lampung Pepadun dan Saibatin/Pesisir, Pemerintahan, Adat Istiadat, Sastra, Bahasa (Jakarta: Way Lima Manjau, 2013), 6.

${ }^{12}$ (Sabarudin, 2013, hlm. 5-6) 
Belenguh (the ancestor of Pesisir people, Pa'lang (the ancestor of Pubian people), Panan (disappeared), and Sangkan (unknown). Another document founded in Way Lima states that the origin of the Lampung ancestors came from Pagaruyung and wandered in Sekal Brak (Lemasa Kepampang). The ancestors had two children namely Umpu Sidenting (settled in Tulang Bawang) and up to the present time known as the Lampung community located papadum and Umpu Peranong (settled in Belalau) which became known as saibatin civil society ${ }^{13}$.

Fourth, according to Muhammad Yamin, and Hilman Hadikusuma that the word Lampung comes from Chinese, to-hang p'ohwang, which is a Lampung or messenger from Lampung, or also Tulang Bawang. Fifth, according to Lampung Resident I (1829-1834) states that the word Lampung is derived from the hereditary folklore of Poyang Si Lampung. It is narrated in a book titled "Majapahit History" which was discovered in 1818, it is narrated that Dewa Senembahan and Widodari Sinuhun had three children, namely the Javanese, the queen of Majapahit, the Pasundan queen Pajajaran and the Lampung queen Belalau. The Lampung at the foot of Mount Pesagi and the descendants are scattered in Lampung area until now in Ranau, Komering to grand wood since the XV century ${ }^{14}$.

Lampung history was begun in the pre-history period, since $1 \mathrm{AD}$, some historical relics that can be used as evidence that there was life in the time, among others: First, the discovery of Kyokken Moddiger, in the form of piles of shells that have been petrified, traces of human food remains in the past, found in Way Mawullah near the border of Lampung and Bengkulu. Second, a statue in the shape of a rhino that is thought to have been made by pre-history humans, found in Batu Badak village, Central Lampung Regency. Third, Batu Tuan Statue found in Balik Bukit Sub-District of Central Lampung Regency. Fourth, the Land Urn containing stone axes found on the North Coast of West Lampung Regency ${ }^{15}$.

After the Pre-history period, Lampung began to enter the Hindu and Buddhist eras marked by the influence of two religions originating in India. Hindu-Buddhist influences have spread and influenced society in its time. The evidence of Hindi and Buddhist influence can be seen from several archaeological discoveries including, First, Umbu Nandi statue in Muara Way Batu Laka, Malay village of North Lampung Regency. Second, Arca Orang in Pugung Raharjo, East Lampung regency. Third, the Elephant Statue in The Colonists of South Lampung regency and the Inscription of Besemah or Palas Pesemah. Regarding the origin of Lampung people came from the Tumi tribe which at that time still adhered to animism and some Hindus and Buddhists who lived around the 7th century $\mathrm{AD}$ which left many inscriptions and 
temples ${ }^{16}$. In addition to the influence of local traditions and local rulers, it seems that in the 7th century AD, there was also influence from the Srivijayan kingdom in Palembang. Then after Srivijaya fell, it began to enter the influence of Islam into Lampung around $1530 \mathrm{AD}^{17}$.

During the Hindu-Buddhist period in Lampung area, several governments formed with a unique system. It can be proven when Banten began to enter Lampung in $1530 \mathrm{M}$, in Lampung area, there are already several areas of Keratuan (Indigenous Law Alliance) consisting of four Keratuan. First, Keratuan in Puncak, which controls the territory of Abung and Tulang Bawang. Second, The Keratuan Pemanggilan that controlled the areas of Krui, Ranau, and Komering. Third, Keratuan Pugung who controlled the territory of Pugung and Pubian. Fourth, Keratuan Balau's power ruled around Teluk Betung 18 .

Before Islam entered Lampung, it was seen that the influence of Hinduism and Buddhism was strong enough to originate from the Sriwijaya kingdom. However, archaeological evidence of the influence of religion was not enough, such as in Java. The influence of the Srivijayan kingdom in Lampung was quite long around the VII century and the beginning of the XV century AD. Then began to enter the influence of Islam originating from Banten kingdom as evidenced by various historical and archaeological relics ${ }^{19}$.

\section{The Ulama Disseminating Islam In Lampung}

There are several theories about the wave of Islam in Lampung. First, Islam is under the ruler or prince of Pagaruyung to Lampung. As explained in the background of the problem that Lampung people come from Sekala brak area (now including Balik Bukit-Lampung Barat sub-district), and after the expansion is in west coast regency, and the residents are called Tumi people (Buay Tumi). They were influenced by four Islamic leaders, namely Umpu Nyerupa, Umpu Bejalan in Way, Umpu Peranong, and Umpu belunguh. Umpu-umpu is called the forerunner of the mountains of West Sumatra (Pagaruyung).

Second, Islam was brought directly by merchants from Gujarat India. In early 1128 AD, Islam entered Lampung with Gujarati merchants, and they lived in Muara Pasai and Perlak who came to Lampung, not from Banten ${ }^{20}$.

Third, Islam entered Lampung because of the influence of Banten

16 Syaiful Anwar, "Naskah Seni Tari Lampung Pesisir Daerah Lampung," Departemen Pendidikan dan Kebudayaan, Proyek Pusat Pengembangan Kebudayaan Lampung, (Bandar Lampung : 1979),20.

${ }^{17}$ Sabarudin, Lampung Pepadun dan Saibatin/Pesisir, Pemerintahan, Adat Istiadat, Sastra, Bahasa, 2-3.

${ }^{18}$ Ibid., h. 2.

${ }^{19}$ Wijayati, “Jejak Kesultanan Banten di Lampung Abad XVII'," 401.

${ }^{20}$ (Departemen Pendidikan dan Kebudayaan - Direktorat Sejarah dan Nilai Tradisional, 1978, hlm. 15) 
kingdom established by Fatahillah. One version of Islamic entry into Lampung after Fatahillah came to Lampung and married Puteri Sinar Alam from South Lampung. The marriage was actually for political purposes because to expand the influence of Banten kingdom and at the same time spread Islam in Lampung. From the result of his marriage was born a son named Muhammad Zaka Waliyullah Ratu Darah Putih, founder of Keratuan Pugung in Kuripan, South Lampung and became the forerunner of Raden Intan, a National hero. He died on October 5, 1856, against the Dutch. The influence of Banten sultanate can also be seen from the tomb of Banten ulamas found in South Lampung. It is archaeological evidence of the existence of Banten ulamas who spread Islam in Lampung ${ }^{21}$.

Fourth, Islam developed in Lampung after entering through the influence of the Sultanate of Palembang. In addition to being closer, Palembang is a place of marketing pepper abroad, while Lampung is a pepper producer 22. Fifth, another opinion states that Islam in Lampung originated in Aceh. As the results of the study conducted by the Research Team of the Faculty of Teachers, Lampung University, based on archaeological evidence of headstones found in Kampung Muara Batang, Palas Sub-District, South Lampung in 1971. The tombstone has the same shape and motif as the tombstone of Sultan Malik Ash-Shaleh in Pasai. ${ }^{23}$

The influence of Islam that is so strong in Lampung tradition and culture is still relatively well maintained. Obviously, Islam is embraced by some of the natives of Lampung or Ulun Lampung. It can be seen from various traditional ceremonies that always begin with various rituals that breathe Islam, including in Lampung poems and songs that sound nuanced with tambourine or gambus music and other aspects of customs culture. Based on its customs, Lampung's people are divided into two broad groups: The People of Pepadun and Saibatin or Peminggir. First, the Lampung Pepadun in detail can be classified into:

a. Abung Siwo Mego (Abung Sembilan Marga) consisting of Buai Nunyai, Buai Unyi, Buai, Nuban, Buai Subing, Buai Beliuk, Buai Kunang, Buai Selagai, Buai Anak Tuha, dan Buai Nyerupa.

b. Megou Pak Tulangbawang (Empat Marga Tulangbawang) consisting of Buai Bolan, Buai Umpu, Buai Tegamoan, dan Buai Ali.

c. Buai Lima (Way Kanan/Sungkai) consisting of Buai Pemuka, Buai bahuga, Buai semenguk, Buai baradatu dan Buai Barasakti.

d. Pubian Telu Suku (Pubian Tiga Suku) consisting of Buai Manyarakat, Buai Tmab Pupus dan Buai Buku Jadi. ${ }^{24}$

Second, the people who adhere to Saibatin or Peminggir or Coastal

${ }^{21}$ Wijayati, "Jejak Kesultanan Banten di Lampung Abad XVII'," 385.

22 (Sabarudin, 2013, hlm. 4)

${ }^{23}$ (Zuraida dkk., 2006, hlm. 19)

${ }^{24}$ (Supriyanto, Sanak Liwa - Lampung Barat | Hanya dengan mengingat Allah hati menjadi tenang., t.t.) 
customs are broadly composed of several indigenous communities: Peminggir, Melinting Rajabasa, Peminggir Teluk, Peminggir Semangka, Sekala Brak, and Peminggir Komering. ${ }^{25}$

Some theories about ulamas who are well-known in the spread of Islam in Lampung are quite numerous. However, the relationship between one cleric and another in spreading Islam in Lampung has not been seen. First, Islamic theory originated in Banten accompanied by archaeological relics, mentioning that Islam was spread directly by Fatahillah (ruler of Banten). Fatahillah, as one of the sultans of Banten or Sunan Gunung Jati or Syarif Hidayatullah, was one of the ulama who joined Wali Songo. Fatahillah was a political leader and a cleric who had links to other Sunnis in the spread of Islam in Java ${ }^{26}$. The next generation of ulama who spread Islam in Lampung can be seen from the relics in the form of tombs in various places. Such as the tomb of Tubagus Haji Muhammad Sholeh in Pagar Dewa Tulang Bawang Barat, the tomb of Tubagus Machdum in Kuala, Teluk Betung Selatan, and the tomb of Tubagus Yahya in Lempasing. Judging by the name, they are still the descendants of Sultan Hasanudin in Banten. ${ }^{27}$ Then there is the one of Arab descent, Habib Ali bin Aly al-Idrus, whose tomb is located in Ketapang South Lampung. ${ }^{28}$ Islam entered from Banten through the Labuhan Maringgai line in Keratuan Pugung, precisely in 1525.

Second, Islam spread from west of Lampung precisely in the area of Sekala Brak Kingdom ${ }^{29}$, and it was the successor of the Islamic kingdom of Pagaruyung. Islam was brought by ulama from West Sumatra, namely the four sons maulana Umpu Ngegalang Paksi; they are Umpu Bejalan in Way, Umpu Belunguh, Umpu Nyerupa, and Umpu Pernong. The word Umpu, derived from the word Ampu Tuan (in Pagaruyung), is a term for the king's children in Pagaruyung. ${ }^{30}$

Third, Islam entered Lampung from the north due to the influence of Palembang Sultanate after the collapse of Sriwijaya. There is a theory that Islam entered through Komering. At that time, Palembang was led by Aria Damar, who had ties to the Kingdom of Demak in Java. Islam was carried by Minak Kemala Bumi or also known as Minak Patih Prajurit. His tomb is Pagar Dewa, Tulang Bawang Barat. It is adjacent to the tomb of Tubagus Haji Muhammad Sholeh, an Islamic spreader from Banten.

${ }^{25}$ (Supriyanto, Sanak Liwa - Lampung Barat | Hanya dengan mengingat Allah hati menjadi tenang., t.t.)

${ }^{26}$ Mahrus El-Mawa, "Rekonstruksi Kejayaan Islam di Cirebon Studi Historis pada Masa Syarif Hidayatullah (1479-1568)," Jumantara, 2012.

27 Ninik Junaidah, “Islam di Lampung 1552-1570” (Yogyakarta, Universitas Islam Negeri Sunan Kalijaga Yogyakarta, 2008), 2.

28 Hilman Hadikusuma, Adat Istiadat Daerah Lampung (Bagian Proyek Pengkajian dan Pembinaan Nilai-Nilai Budaya Daerah Lampung, 1996), 45.

${ }^{29}$ Ahmad Ridho al- Amin dkk, Sejarah Masuknya Islam di Lampung, (STAIN Metro: 2015).

${ }^{30}$ Agus Setyawan, Budisantoso Budiman, and Oyos Saroso H. N, Merajut Jurnalisme Damai di Lampung (Bandar Lampung: AJI Bandar Lampung, 2012), 16-17. 
, Vol. 25, No. 02 Juli - Desember 2020

A historical source also mentioned that the close relationship between Lampung and Banten is indicated by twelve Penggawa from various Kebuaian visiting Banten to study Islam. They are Penggawa from Bumi Pemuka, Buai Subing, Buai Berugo, Buai Selagai, Buai Aji, Buai Teladas, Buai Bugis, Buai Cempaka, Buai Kamatero, and Buai Bunga Mayang. The bonds or relationships of Lampung and Banten in the past can also be found in the form of brotherhood agreements written in and relics in the form of Adat Law or Kuntara Raja Niti, a law book written in Banten with Arabic script and Lampung language with Lampung script.

Furthermore, in the following generation, around 1883, when Mount Krakatau erupted in the southern Bay of Betung area, some clerics spread Islam. He was named Abdurahman or Sheikh Ngabehi, a Warlord from Banjar, South Kalimantan. He married a local named Tuyuk Beringin, precisely in the village of Pedagan (Sukarame), and spread Islam in the area. Tuyuk Beringin himself is the daughter of Bakhang from Kenali and Biha, West Lampung. The remains of Sheikh Ngabehi are manuscripts of the Qur'an written in squid ink. ${ }^{31}$ In addition to Sheikh Ngabehi, there is another name, Sheikh Jambu Manglid, who spread Islam in the village of Air Naningan, Tanggamus, in the 16th century. He spread Islam through the culture of puppet art and song. ${ }^{32}$ Later, the name of another Islamic cleric in Lampung was Tuan Alim Pandita Ratu or the original name of Sheikh Muhammad Alim al-Madinah, from Banten, the son of Sheikh Soiman. $\mathrm{He}$ spread Islam in Bandar Lampung, Gedong Aji, Bakung, and Karta. During his lifetime, Sheikh Tuan Alim Pandita Ratu preached until he died in 1773. ${ }^{33}$

The number of Islamic clerics in Lampung shows that the Process of Islamization is fascinating to trace through a historical study in this study. Figures known in the spread of Islam in Lampung are successfully revealed in research based on the periodation and transmission of a very diverse clerical background and its origins. Based on the results of research conducted on the network of Islamic dissemination, Ulama in Lampung can be presented in the following table:

Table 1. The Table of Ulama Spreading Islam in Lampung

\begin{tabular}{|l|l|l|c|}
\hline No. & \multicolumn{1}{|c|}{ The Name of Ulama } & \multicolumn{1}{c|}{ Origin } & \multicolumn{1}{c|}{ Year } \\
\hline 1. & $\begin{array}{l}\text { Syarif Hidayatullah/ } \\
\text { Sunan Gunung Djati }\end{array}$ & Cirebon-Banten & $1525 \mathrm{AD}$ \\
\hline
\end{tabular}

31 admin, "Syekh Ngabihi Terdampar di Lampung Sebagai Tokoh Penyebar Islam," Traznews (blog), December 4, 2017, https://traznews.com/beritaindonesia/syekh-ngabihi-terdampar-di-lampung-sebagai-tokoh-penyebar-islam/.

${ }^{32}$ Evi Kusmiana, Iskandar Syah, and M. Basri, "Penyebaran Agama Islam oleh Sekh Jambu Manglid Pada Abad Ke-16 Di Desa Airnaningan Kecamatan Airnaningan Kabupaten Tanggamus," Jurnal FKIP, UNILA, Provinsi Lampung, n.d.

33 "Mengenal Tuan Alim Pandita Ratu; Penyebar Agama Islam di Lampung," accessed November 12, 2020, https://www.dutaislam.com/2018/01/mengenal-tuanalim-pandita-ratu-penyebar-agama-islam-di-lampung.html. 


\begin{tabular}{|c|c|c|c|}
\hline 2. & $\begin{array}{l}\text { Sayyid Maulana Malik } \\
\text { Abdullah }\end{array}$ & $\begin{array}{l}\text { Banten, allegedly is } \\
\text { still the descendant } \\
\text { of Syarif } \\
\text { Hidayatullah }\end{array}$ & $\begin{array}{l}\text { It is not known for } \\
\text { certain, the possibly } \\
\text { in the } 16^{\text {th }} \text { century } \\
\text { AD }\end{array}$ \\
\hline 3. & $\begin{array}{l}\text { Syeikh Muhammad Alim } \\
\text { al-Madinah (Tuan Alim } \\
\text { Pandita Ratu) }\end{array}$ & Banten & $\begin{array}{l}\text { 1700s. } \\
\text { Died in } 1773 \text { AD. }\end{array}$ \\
\hline 4. & $\begin{array}{l}\text { Maulana Umpu } \\
\text { Ngegalang Paksi } \\
\text { (Maulana Imam al-Hasyr) }\end{array}$ & $\begin{array}{l}\text { Pagarurung } \\
\text { Sumatera Barat }\end{array}$ & $\begin{array}{l}\text { Around } 14^{\text {th }} \text { century } \\
\text { AD }\end{array}$ \\
\hline 5. & $\begin{array}{l}\text { Syeikh Aminullah } \\
\text { Ibrahim }\end{array}$ & $\begin{array}{l}\text { Probably from Arab } \\
\text { or Aceh }\end{array}$ & $1525 \mathrm{AD}$ \\
\hline 6. & $\begin{array}{l}\text { Ratu Menangsi } \\
\text { (Muhammad Malik } \\
\text { Badri) } \\
\end{array}$ & Lampung & Unknown \\
\hline 7. & Ratu Darah Putih & Lampung & \\
\hline 8. & Pamutokh Agung & Lampung & $16^{\text {th }}$ century AD \\
\hline 9. & Raden Intan II & Lampung & Died 1856 AD \\
\hline 10. & Syeikh Jambu Manglid & $\begin{array}{l}\text { Jawa, probably the } \\
\text { apprentice of Sunan } \\
\text { Kalijaga }\end{array}$ & Died 1625 AD \\
\hline 11. & $\begin{array}{l}\text { Al-Habib Ali bin Alwi bin } \\
\text { Abdurrahaman Alydrus }\end{array}$ & Arab & $\begin{array}{l}\text { Died } 1883 \text { AD within } \\
\text { the eruption of } \\
\text { Krakatau }\end{array}$ \\
\hline 12. & Syeikh Ngabihi & $\begin{array}{l}\text { Banjar Kalimantan } \\
\text { Selatan }\end{array}$ & Unknown \\
\hline 13. & Tubagus mahdum & Banten & $\begin{array}{l}\text { Died in the end of } \\
1700 \mathrm{~s}\end{array}$ \\
\hline 14. & Tubagus Yahya & Banten & Died in $1930 \mathrm{AD}$ \\
\hline 15. & $\begin{array}{l}\text { Wali (Wak Ali) Samin bin } \\
\text { Muhammad }\end{array}$ & Serang, Banten & $1900 \mathrm{~s}$ \\
\hline 16. & $\begin{array}{l}\text { Tubagus Buang Gunung } \\
\text { Kunyit (Haji Muhammad } \\
\text { Soleh bin Puwang } \\
\text { Karaeng Petajanggu) }\end{array}$ & $\begin{array}{l}\text { Bone Sulawesi } \\
\text { Selatan, Obtained } \\
\text { the title Tubagus } \\
\text { because he was } \\
\text { given the duty from } \\
\text { the Sultan of Banten } \\
\text { to spread Islam in } \\
\text { Lampung and was } \\
\text { recognized as a } \\
\text { relative of Sultan } \\
\text { Hasanuddin. }\end{array}$ & $15^{\text {th }}$ century AD \\
\hline
\end{tabular}


, Vol. 25, No. 02 Juli - Desember 2020

\begin{tabular}{|c|c|c|c|}
\hline 17. & Tubagus Ali Fakih & Banten & $1900 \mathrm{~s}$ \\
\hline 18. & Tubagus Sangkrah & Banten & $1900 \mathrm{~s}$ \\
\hline 19. & Syeikh Nambihi & Banten & $1936 \mathrm{AD}$ \\
\hline 20. & KH. Gholib & $\begin{array}{l}\text { Krian, Sidoarjo, } \\
\text { Jawa Timur }\end{array}$ & Died in $1949 \mathrm{AD}$ \\
\hline 21. & KH. Ahmad Hanafiah & $\begin{array}{l}\text { Sukadana, } \\
\text { Lampung Timur }\end{array}$ & 1905-1947 AD \\
\hline 22. & $\begin{array}{l}\text { KH. Raden Rahmad } \\
\text { Djoyo Ulomo }\end{array}$ & Kediri Jawa Timur & $1878 \mathrm{AD}$ \\
\hline 23. & KH. M. Arief Mahya & $\begin{array}{l}\text { Liwa, Lampung } \\
\text { Barat }\end{array}$ & 1926-now \\
\hline 24. & $\begin{array}{l}\text { KH. Nur Muhammad } \\
\text { Abdurrahim Busthamil } \\
\text { Karim }\end{array}$ & $\begin{array}{l}\text { Kebumen Jawa } \\
\text { Tengah }\end{array}$ & $1890 \mathrm{AD}$ \\
\hline 25. & KH. Sulaiman Rasyid & $\begin{array}{l}\text { Liwa, Lampung } \\
\text { Barat }\end{array}$ & 1896-1971 AD \\
\hline
\end{tabular}

Based on the table, the Islamic scattering ulama in Lampung are not predominantly from specific areas, but they come from different regions. Lampung ulama come from local people who also struggle to spread Islam in Lampung. ${ }^{34}$ Entering the 20th century, more and more diverse ulama continued the tradition of Islamic da'wah that continued to develop and enrich the local culture with the cultural acculturation of the origin of the ulama while maintaining and respecting Lampung customs and culture as a form of accommodation and preservation of local culture.

\section{Islam Within The Dinamics of Lampung Culture and Tradition}

In detail, the philosophy of life of Piil Pesenggiri, according to Hadikusuma (1989), consists of five living philosophy derived from the local wisdom of Ulun Lampung (Lampung People):

1. Pesenggiri, means abstinence, does not want to lose in the attitude of action and behavior.

2. Juluk Adek or Juluk Adok, Beadok, means loving a good name and honorable title.

3. Nemui Nyimah contains the meaning of accepting and giving an atmosphere of love and sorrow.

4. Nengah Nyappur contains the meaning of associating and consultation in solving a problem.

5. Sakai Sambayan means to help and to go together, in kinship and neighborly relationships. 
Based on Piil Pesenggiri, according to Hadikusuma, the philosophy is applied by Ulun Lampung, especially in the people of Lampung Pepadun. It influences their attitudes and prominent character. While in the indigenous people of Lampung Pesisir (Sai Batin), the attitude, disposition, and behavior are not visible. If it does exist, its nature is limited among its customary elders, like the Pi'il of Raden Intan, who fought the Dutch in Kalianda until he died in 1865 AD, also like the Piil of Mangku Negara in fighting the Dutch in the Pubian area and disappeared in the same year. ${ }^{35}$

The role of ulama in the spread of Islam in Lampung is very accommodative. It respects the local ordinances, customs, and culture of Lampung people, which are considered ancestral heritage that must be preserved as long as it is not opposed to Islamic values. The culture and philosophy remain because it contains the principles of Islamic teachings in the content of every philosophy of life. Islamic teachings influence other traditional ceremonies that are still preserved in the middle of the Lampung community. It is performed in the birth ceremony, circumcision, marriage, even death ceremony, everything related to Islamic teachings as a religion embraced by most Lampung people.

In addition to the philosophy of life of Piil Pesenggiri coming from the people of Lampung Pepadun, there is also a traditional philosophy of Lampung Sai Batin. As a result of interviews with Lampung historical figures, especially Lampung Sai Batin, Aki Darmansyah, at the IAIN metro collaborative research event on July 20, 2019, Krui, Pesisir Barat Regency. Darmansyah explains chronologically the history of Ulun Lappung. According to him, among the indigenous peoples of Lampung Saibatin, there is also life philosophy known as Pegung Pakai (Guide/Handle of Life), which is found in the book of Simbur Cahaya. First, Liwon Angkon Asuh and Asih (the leader must protect his community). Second, Muali Mufakat (Musyawara Mufakat), Third, Sesakai Gawen Sumban Sakai (Behavior). Fourth, Sai Balak Balak Balak, Sai Lunik event Lunik, Sai Tuha ala Dirasa sai Duha ala in Gawi (prioritizing mutual cooperation). Fifth, Mak Mulang ke Mak Menang, Kik Kalah Mandi Hilang, (do not go home if not win, a ban or abstinence, as well as motivation to achieve the goal in earnest).

Pegung Pakai philosophy takes place among Lampung Saibatin. There is also a motto of sticking to Syara' (Islamic law) and the Book of Allah (Qur'an). ${ }^{36}$ This is somewhat similar to the spirit of the Paderi in West Sumatra, Adat Basando Syara', and Syara' Basando Kitabullah. Perhaps, it is still affected by the link between the Pagaruyung kingdom that has Islamicized west Lampung and then spread to other areas. The essence of Piil Pesenggiri and Pegung Pakai philosophy is strongly reflected in Lampung people's philosophy of life and daily behavior.

35 Farida Ariyani et al., Konsepsi Piil Pesenggiri Menurut Masyarakat Adat Lampung Waykanan di Kabupaten Waykanan (Aura Printing \& Publishing, 2015), 38.

${ }^{36}$ Aki Darmansyah, Wawancara dan Paparan Tokoh Sejarah dan adat-budaya Lampung, July 20, 2019. 
Islamic values in Lampung tradition and culture can also be found in traditions and cultures called Muakhi. In Pubian indigenous peoples, namely the values of brotherhood between groups and become a reasonable moral basis in Lampung society, in solidarity, brotherhood, mutually beneficial cooperation, intense social interaction, local wisdom, and peace that spells out in the community. ${ }^{37}$ The word Muakhi probably comes from the words "Akhun," 'Ikhwan" which means brother, and in Muakhi as ethical values are realized and cultured for a long time in the indigenous peoples in Lampung. In the tradition of helping each other, for example, the older brother (Kiay, Kanjeng) is holding his son's wedding using traditional ceremonies, hence the willingness to sacrifice to help his brother becomes an expected value. Furthermore, if any of the other brothers do not care, it will undoubtedly get social sanctions from the citizens. ${ }^{38}$

Lampung tradition and culture are affluent. Of course, there are still many customs and cultures that come into contact with Islamic religious values because the relationship or contact of local culture and Islamic religious values have occurred over a long period. For example, in the customs of marriage, there is the term "Ngarak Maju" which uses a tambouric music instrument containing Arabic acuity and Sholawat Nabi, Zikir, and Berjanzi poems, hadrah art (Butabuh). Then the event "Betamat" is to read the scriptures of the Qur'an in the procession of marriage or circumcision. It is usually read at night and in circumcision, by paraded children from the religion teacher's place. Another event is Tahlilan if any members die by reading the Qur'an for seven days. While in social relations between bachelor and girl, there is an Islamic rule known as Cempala Khua Belas. It regulates the relationship between bachelors and girls, as well as sanctions in the event of violations. This regulation is influenced by Islamic law, which contains decency and politeness. ${ }^{39}$ Islamic values strongly influence Lampung tradition and culture. Until now, it is not easy to separate between local culture and Islamic values among Lampung people. To explore the variety of Islamic cultures that influence Lampung customs and culture is still very open to study and research in an academic context because of the richness of the culture as a treasure and the wealth of local wisdom of Lampung ancestors.

In local literacy, which results from Lampung intellectual property, some cultural relics and other customs such as Lampung script and Lampung language are said to have a relationship with Pallava letters from South India. It is also called Had (Khot in Arabic, meaning calligraphy), ${ }^{40}$ which has 20 pieces of mother letter. Had Lampung is also called Ka Ga Nga. Then there is a custom called Gawi Adat, a massive event that aims to give Saibatin title

37 "Akulturasi Islam dalam Budaya Lampung," accessed November 12, 2020, https:/ / www.lampost.co/berita-akulturasi-islam-dalam-budaya-lampung.html.

38 "Akulturasi Islam dalam Budaya Lampung."

${ }^{39}$ (Sejarah Negara Com, t.t.)

${ }^{40}$ (Udin \& Pusat Pembinaan dan Pengembangan Bahasa, 1998, hlm. 35) 
through deliberation or agreement of Indigenous people. Besides, there is the term Cangget Agung which is a dance played by young men and young people at the time of the traditional ceremony of the appointment of a customary head (Cacak Pepadun) ${ }^{41}$. The mention of the word "Khad" in Arabic means letters) indicates that the influence of Arabic as a reflection of Islam's spread and its influence on Lampung's customs and culture is so strong. It is displayed in Lampung script commonly referred to as Had Lampung.

Lampung's cultural richness is remarkable because the people are scattered in various regions, and various clans or Kebuayan in Lampung. Nevertheless, the influence of Islam is significant to the tradition and culture of Lampung. It can be seen from some traditional ceremonies that are thick with religious nuance, especially Islamic values. First, Kuruk Liman, it is a rite of seventh-month pregnancy. Second, the "Saleh Darah" is the birth ceremony of the baby. Third, "Mahan Manik," the ceremony of coming down to the ground when the baby is forty days old. Fourth, Circumcision ceremony when the child is five years old. Fifth, the "Serah Sepi," is the ceremony when the teenager starts at 17 years old. Sixth, the wedding ceremony and if any relatives die (death). Seventh, the ceremony "Cokok (Cakak) Pepadun," is an inauguration of a new customary weigher as the head of adat and others. Perhaps there are many more traditions or cultural customs that breathe Islam because the two have fused and formed a kind of social cohesion or even a social system. So solidly, the elements of Islamic teachings always reflected and spelled out in Lampung customs and culture that are considered sublime and have great value in maintaining Lampung people's cultural identity. The influence of Islam can also be seen in Lampung's traditional clothing. It represents the concept of closing the awrah, and the clothes are only used in various traditional events and cultures of Lampung. Siger Lampung's traditional clothing, Tapis Lampung sand, so on contain the noble values of Lampung people and local wealth and wisdom that until now is still very maintained. However, times have changed from one generation to another.

\section{E. Conclusion}

Based on the above findings, it turns out that Islamic preachers in Lampung, who come from various regions as described theory, preached by using accommodating da'wah methods toward the local cultural diversity. The ulamas who spread Islam in Lampung from various generations did not dispute Islamic teachings and the philosophy or cultural wisdom of Lampung people. One of the philosophies of life that are still entrenched among the people or Ulun Lampung is Pi'il Pesenggiri (Juluk Adok/Adek, Nemui Nyimah, Nengah Nyappur, Sakai Sambayan). The process of Islamic entry into Lampung is also carried out by the cultural acculturation process 
AKADEMIKA: Jurnal Pemikiran Islam

, Vol. 25, No. 02 Juli - Desember 2020

so that the long-standing culture remains sustainable. Some researchers of Ulun Lampung's life philosophy consider that Islamic teachings strengthen life philosophies such as brotherhood, moderate attitude, friendly, mutual cooperation, and etcetera. Some of the Islamic dissemination ulamas in Lampung are biographically from various regions in Indonesia. The most dominating are from Banten, some also come from Lampung, and some are from Java and other areas. 


\section{REFERENCES}

admin. (2017, Desember 4). Syekh Ngabihi Terdampar Di Lampung Sebagai Tokoh Penyebar Islam. Traznews. https://traznews.com/beritaindonesia/syekh-ngabihi-terdampar-di-lampung-sebagai-tokohpenyebar-islam/

Akulturasi Islam dalam Budaya Lampung. (t.t.). Diambil 12 November 2020, dari https://www.lampost.co/berita-akulturasi-islam-dalam-budayalampung.html

Ariyani, F., Yufrizal, H., Agustina, E. S., \& Mustofa, A. (2015). Konsepsi Piil Pesenggiri Menurut Masyarakat Adat Lampung Waykanan Di Kabupaten Waykanan. Aura Printing \& Publishing.

Darmansyah, A. (2019, Juli 20). Wawancara dan paparan tokoh sejarah dan adatbudaya Lampung [Komunikasi pribadi].

Departemen Pendidikan dan Kebudayaan - Direktorat Sejarah dan Nilai Tradisional, I. (1978). Geografi Budaya Lampung (P. Mayong, Ed.). Direktorat Sejarah dan Nilai Tradisional.

El-Mawa, M. (2012). Rekonstruksi Kejayaan Islam Di Cirebon Studi Historis Pada Masa Syarif Hidayatullah (1479-1568). Jumantara, 3(1), 100-127.

Geertz, C., \& Taufik Abdullah. (2013). Agama Jawa: Abangan, santri, priyayi dalam kebudayaan Jawa. Komunitas Bambu.

Hadikusuma, H. (1996). Adat istiadat daerah Lampung. Bagian Proyek Pengkajian dan Pembinaan Nilai-Nilai Budaya Daerah Lampung.

Imron, A. (1991). Kuntara raja niti: Tra [n] skripsi naskah kuno dan analisis sejarah. Universitas Lampung.

Junaidah, N. (2008). Islam Di Lampung 1552-1570. Universitas Islam Negeri Sunan Kalijaga Yogyakarta.

Kusmiana, E., Syah, I., \& Basri, M. (t.t.). Penyebaran Agama Islam Oleh Sekh Jambu Manglid Pada Abad Ke-16 di Desa Airnaningan Kecamatan Airnaningan Kabupaten Tanggamus. Jurnal FKIP, UNILA, Provinsi Lampung.

Lampung Tradition: Adat Istiadat Lampung. (t.t.). Diambil 12 November 2020, dari http:/ / adatlampungs49.blogspot.com/2014/03/adat-istiadatlampung.html

Marsden, W., Sutrisno, \& Wijayanti, D. (2016). Sejarah Sumatera.

Martiara, R. (2012). Nilai dan norma budaya Lampung dalam sudut pandang strukturalisme. Program Pascasarjana, ISI Yogyakarta.

Martiara, R. (2014). Cangget: Identitas kultural Lampung sebagai bagian dari keragaman budaya Indonesia.

Meleong, L. J. (1989). Metologi penelitian kualitatif. PT Remaja Rosdakarya.

Mengenal Tuan Alim Pandita Ratu; Penyebar Agama Islam di Lampung. (t.t.). Diambil 12 November 2020, dari https://www.dutaislam.com/2018/01/mengenal-tuan-alim-panditaratu-penyebar-agama-islam-di-lampung.html

Moh. Nazir. (1991). Metode Penelitian. Ghalia Indonesia. 
, Vol. 25, No. 02 Juli - Desember 2020

Sabarudin. (2013). Lampung Pepadun dan Saibatin/Pesisir, Pemerintahan, Adat Istiadat, Sastra, Bahasa. Way Lima Manjau.

Sang Bumi Ruwa Jurai, artinya satu bumi dua aliran adat dan budaya. Kata sang Bumi berasal dari kata "Sanga Bumi" artinya Se-bumi. Sedangakan "Ruwa Jurai" artinya dua aliran (kelompok) budaya yang berbeda yaitu aliran (jurai/marga), yaitu masyarakat Sebatin/Sai Batin (pesisir) dan Pepadun yang tinggal didataran tinggi. Ada juga yang menyebutnya dengan istilah Bumi Ruwai Jurai. Dilihat dari silsilah Sai Batin berasal dari kerajaan "Paksi Sekala Brak", sedangkan kerajaan "Abung Siwo Megow", menjadi cikal bakal masyarakat Pepadun. (t.t.).

Sejarah Negara Com: Akulturasi Islam dan Budaya Lampung. (t.t.). Diambil 12 November 2020, dari https://www.sejarah-negara.com/

Setyawan, A., Budiman, B., \& Oyos Saroso H. N. (2012). Merajut jurnalisme damai di Lampung. AJI Bandar Lampung.

Supriyanto, Sanak Liwa-Lampung Barat | Hanya dengan mengingat Allah hati menjadi tenang. (t.t.). Diambil 12 November 2020, dari https:/ / supriliwa.wordpress.com/

Syahputra, M. C., \& Riyansyah. (2017). Napaktilas jejak Islam Lampung.

Syaiful Anwar, Naskah Seni Tari Lampung Pesisir Daerah Lampung, Departemen Pendidikan dan Kebudayaan, Proyek Pusat Pengembangan Kebudayaan Lampung, (Bandar Lampung: 1979). H. 20. (t.t.).

Udin, N., \& Pusat Pembinaan dan Pengembangan Bahasa (Ed.). (1998). Sastra lisan Lampung dialek Pubiyan. Pusat Pembinaan dan Pengembangan Bahasa, Departemen Pendidikan dan Kebudayaan.

Wijayati, M. (2011). Jejak Kesultanan Banten di Lampung Abad XVII'. Jurnal Analisis, 11(2), 383-420.

Zuraida, K., Giri Gunadi, I. M., \& Zanariah. (2006). Peninggalan kebudayaan Islam Lampung koleksi Museum Lampung "Ruwa Jurai" (O. Laksito, Ed.). Dinas Pendidikan Provinsi Lampung, UPTD Museum Negeri Provinsi Lampung "Ruwa Jurai." 